\title{
THE EFFECTS OF NICKEL APPLICATIONS ON THE GROWTH OF COCKLEBUR (XANTHIUM STRUMARIUM L.) PLANT
}

\author{
EREN, A. \\ Department of Crops and Animal Production, Kiziltepe Vocational Training High School, \\ Artuklu University, 47200 Mardin, Turkey \\ (e-mail: abdullaheren@artuklu.edu.tr; phone: +90-482-213-4002; fax: +90-482-215-2502) \\ (Received 23 $3^{\text {rd }}$ Oct 2018; accepted $7^{\text {th }}$ Jan 2019)
}

\begin{abstract}
Nowadays the environmental pollution caused by heavy metals is spreading all over the world, especially where the industry is developing rapidly, and soils are polluted very dramatically and hazardously at a high level. In this study, cocklebur-(Xanthium strumarium L.) plants were grown in nickel $(\mathrm{Ni})$ contaminated soil $\left(0,50,100,200\right.$ and $\left.400 \mathrm{mg} \mathrm{Ni} \mathrm{kg}^{-1}\right)$ under greenhouse conditions for 6 weeks to study the ability of $\mathrm{Ni}$ uptake and accumulation of the plants. The $\mathrm{Ni}$ treated plants were compared with the control $\left(0 \mathrm{mg} \mathrm{Ni} \mathrm{kg}^{-1}\right)$ plant. As a result of that comparison, chlorophyll levels of old and young leaves, dry weights, reduced glutathione (GSH), macronutrient concentrations, such as nitrogen $(\mathrm{N})$, phosphor $(\mathrm{P})$, potassium $(\mathrm{K})$, calcium $(\mathrm{Ca})$ and magnesium $(\mathrm{Mg})$ ) and micronutrient concentrations, such as iron $(\mathrm{Fe})$, zinc $(\mathrm{Zn})$, and manganese $(\mathrm{Mn})$ nutrient concentrations of the plants were decreased, whilst the concentrations of $\mathrm{Ni}$ and of copper $(\mathrm{Cu})$ increased with increasing dose of $\mathrm{Ni}$ application. The results show that the studied plant (Xanthium strumarium L.) can be used for the cleaning up of Ni-contaminated soils and is suitable for phytoremediation.
\end{abstract}

Keywords: chlorophyll, heavy metal, mineral element, phytoremediation, pollution

\section{Introduction}

Soil pollution is one of the most important environmental problems nowadays. As stated in the previous studies, major soil pollutants, such as heavy metals, excessive use of fertilizers, pesticides, hormones, organic compounds, industrial wastes and accumulation of dangerous substances in the soil, etc. have become a rising problem as a consequence of human activities (Rahman et al., 2005; Daghan, 2007; Karaca and Turgay, 2012; Daghan and Ozturk, 2015).

Environmental pollution, especially caused by heavy metals such as $\mathrm{Ni}$, lead $(\mathrm{Pb})$, cadmium $(\mathrm{Cd})$, mercury $(\mathrm{Hg})$, chromium $(\mathrm{Cr})$, arsenic $(\mathrm{As})$, zinc $(\mathrm{Zn})$, copper $(\mathrm{Cu})$, has been a research topic and attracted attention of many countries in the world.

Nickel is one of the most commonly found elements in the earth's crust and is located in the $22^{\text {nd }}$ order among the other elements (Kaviani et al., 2017). This element is an essential element for plant growth and development in small doses (Marschner, 1995; Yang et al., 1996; Gheibi et al., 2009). Nickel is a functional component of some enzymes, especially urease (urea amidohydrolase, EC 3.5.1.5) enzyme in the plant. Urease is a metalloenzyme and plays an important role together with nitrogen being the enzyme that catalyzes the hydrolysis of ammonia and carbon dioxide (Dos Reis et al., 2017). Urea is accumulating in the plant tissue under Ni deficiency condition and it causes the toxic effect (Gheibi et al., 2009). Nickel has also function to catalyze enzymes for nitrogen fixation in legumes plants and increased tolerance to plant disease (Gerendás et al., 1999). However, at high concentrations Ni exhibits a toxic effect, negatively affects photosynthesis and membrane functions, and also prevents seed germination, plant growth and development (Parlak, 2016). 
Many researchers have focused on the effects of heavy metals on human health and the environment, on the detection of contaminated areas, on cleaning methods and facilities to minimize the damage that these areas have on human health and the environment (Chaney, 1988; Ebbs et al., 1997; Gupta and Gupta, 1998; Karenlampi et al., 2000; Yankov et al., 2000; Lombi et al., 2002; Prasad and Freitas, 2003; Murakami and Ae, 2009; Daghan et al., 2012; Syam et al., 2016; Rehman et al., 2018). Remediation of polluted soil is usually done by excavating the contaminated area and renewing the soil that has been cleaned. However, in recent years, technologies applied directly in-situ without digging the earth has gained more attention (Kocaer and Baskaya, 2003).

Phytoextraction is the removal of soil contaminants by plant roots, accumulation in the organs above the soil, and subsequent harvesting of the plants, respectively. This method is especially used on plants to clean up active elements, such as $\mathrm{Zn}$ and $\mathrm{Cu}$, or metals not in the nutrient group like $\mathrm{Ni}$, lead (Pb) and cadmium (Cd) (Hamutoglu et al., 2012).

In the literature, many plants such as Helianthus annuus L. (Ahmad et al., 2011), Nicotiana tabacum L. (Daghan et al., 2012), Oryza sativa L., Zea mays L., (Murakami and Ae, 2009), Sebertia acuminate (Jaffré et al., 2013), Glycine max L. (Syam et al., 2016), Salicornia iranica (Kaviani et al., 2017) have been tested and used for the phytoremediation of heavy metals from the contaminated soil. Likewise, the success of phytoextraction depends on the detection of suitable plant species that can tolerate and accumulate heavy metals and to produce large biomass using conventional agricultural techniques (Syam et al., 2016).

A plant that is selected to be used in phytoremediation methods, should have a great amount of metal accumulation in its shoots and harvested parts, be able to tolerate heavy metal that has accumulated, also has to be deep-rooted and fast growing (Daghan et al., 2012).

The aim of this study is to investigate the potential use of Xanthium strumarium L., which can grow very easily in nature, has a high amount of roots and shoots, also can be grown in $\mathrm{Ni}$ contaminated soil, for heavy metals accumulation and phytoextraction method.

\section{Materials and methods}

In this study, Xanthium strumarium L., which belongs to the Asteraceae family and the Xanthium species was used as plant material. Xanthium strumarium L. is an annual plant which has the ability of self-pollinating. Additionally, it can grow even in the most adverse conditions up to $1 \mathrm{~m}$ and having advanced pile roots and can be found in almost all regions in Turkey (Cesur and Senkal, 2016).

The Pasakoy soil series of Amik Plain was used in experiments as a soil material (Kilic et al., 2008). Some physical and chemical properties of the soil were given in Table 1 .

The air-dried soil sample was sieved from a $4 \mathrm{~mm}$ sieve and then $2 \mathrm{~kg}$ of soil was filled into each pot. In order to obtain a homogeneous distribution in the soil, increasing doses of $\left(0,50,100,200\right.$ and $\left.400 \mathrm{mg} \mathrm{kg}^{-1}\right) \mathrm{Ni}$ were applied in the form of $\mathrm{NiSO}_{4} \cdot 6 \mathrm{H}_{2} \mathrm{O}$ prior to planting, and incubated for 3 weeks. Before planting, each pot was fertilizer with the solutions of $200 \mathrm{mg} \mathrm{kg}^{-1}$ nitrogen $(\mathrm{N})$ in the form of $\mathrm{NH}_{4} \mathrm{SO}_{4}, 100 \mathrm{mg} \mathrm{kg}^{-1}$ phosphorus (P) in the form of $\mathrm{KH}_{2} \mathrm{PO}_{4}$ and $125 \mathrm{mg} \mathrm{kg}^{-1}$ potassium $(\mathrm{K})$ with $2.5 \mathrm{mg} \mathrm{kg}^{-1}$ iron $(\mathrm{Fe})$ in the form of Fe-EDTA. During the experiment (6 weeks) the pots were 
irrigated with pure water in soil field capacity of $60-80 \%$. The experimental design used was completely randomized design with 3 replications in a factorial arrangement.

Table 1. The physical and chemical properties of the soil material

\begin{tabular}{|c|c|c|c|c|c|}
\hline Parameters & Results & References & Parameters & Results & References \\
\hline Structure & Clay & Bouyoucos (1952) & $\mathrm{N}$ & $1.12 \%$ & $\begin{array}{c}\text { Bremner and } \\
\text { Mulvaney (1982) }\end{array}$ \\
\hline $\mathrm{pH}$ & 7.56 & $\begin{array}{c}\text { Soil Survey Staff } \\
\text { (1951) }\end{array}$ & $\mathrm{P}$ & $19.1 \mathrm{P}_{2} \mathrm{O}_{5}$ & $\begin{array}{l}\text { Olsen et al. } \\
\text { (1954) }\end{array}$ \\
\hline Salt & $0.22 \%$ & $\begin{array}{c}\text { Soil Survey Staff } \\
\text { (1951) }\end{array}$ & K & $77.3 \mathrm{~K}_{2} \mathrm{O}$ & Richards (1954) \\
\hline $\mathrm{CaCO}_{3}$ & $45.1 \%$ & Loeppert et al. (1996) & Available Fe & $24.4 \mathrm{mg} \mathrm{kg}^{-1}$ & \multirow{5}{*}{$\begin{array}{l}\text { Lindsay and } \\
\text { Norvell (1978) }\end{array}$} \\
\hline Organic matter & $2.55 \%$ & Kacar (1995) & Available $\mathrm{Cu}$ & $3.73 \mathrm{mg} \mathrm{kg}^{-1}$ & \\
\hline Organic carbon & $1.48 \%$ & Kacar (1995) & Available Mn & $69.7 \mathrm{mg} \mathrm{kg}^{-1}$ & \\
\hline \multirow[t]{2}{*}{ Field capacity } & $32.4 \%$ & Alpaslan et al. (1998) & Available $\mathrm{Zn}$ & $7.40 \mathrm{mg} \mathrm{kg}^{-1}$ & \\
\hline & & & Available Ni & $7.34 \mathrm{mg} \mathrm{kg}^{-1}$ & \\
\hline
\end{tabular}

Before harvesting the leaf chlorophyll contents were measured in 3 replicates by a chlorophyll meter (Konica-Minolta SPAD-502). At the end of the experiment, the plants were harvested about $1 \mathrm{~cm}$ above the soil surface and washed with pure water, and then dried in an oven until they reached a constant weight at $65{ }^{\circ} \mathrm{C}$. Afterward, dry weights of the plants were taken and grounded in a grinding mill (Retsch RM 200) for analysis. Test results were evaluated for the whole plant.

The concentrations of $\mathrm{Ni}, \mathrm{P}, \mathrm{K}, \mathrm{Ca}, \mathrm{Mg}, \mathrm{Fe}, \mathrm{Zn}, \mathrm{Cu}$ and $\mathrm{Mn}$ were measured by the inductively coupled plasma atomic emission spectroscopy (ICP-AES Varian Liberty Series II) instrument by dissolving the grounded plant samples in a microwave (MarsXpress CEM) with nitric acid $\left(\mathrm{HNO}_{3}\right)$. Nitrogen $(\mathrm{N})$ analysis of plant samples was carried out according to the Kjeldahl method (Bremmer and Mulvaney, 1982).

Nickel content (uptake) of Xanthium strumarium L. was calculated as follows (Eq. 1):

$$
\text { Ni content }\left(\mu \text { plant }^{-1}\right)=\left[\mathrm{DW}\left(\mathrm{g} \mathrm{plant}^{-1}\right) \times \mathrm{Ni} \text { concentration }\left(\mu \mathrm{g} \mathrm{g} \mathrm{g}^{-1}\right)\right]
$$

Reduced glutathione (GSH) analysis was performed according to Cakmak and Marschner (1992). The experimental data were evaluated according to the factorial design pattern using the SPSS 22.0 statistical analysis program to determine the significance of levels and grouped by Duncan test according to Bek (1986).

\section{Results and discussion}

The results of $\mathrm{Ni}$ applications effects on the chlorophyll contents of leaves, dry weight, reduced glutathione (GSH) and Ni concentration of Xanthium strumarium L. plant were given in Table 2.

As can be seen on Table 2, the Ni applications cause a reduction in dry weights of Xanthium strumarium L. plant and likewise, chlorophyll contents were also decreased with those applications $(\mathrm{p} \leq 0.01)$. 
Table 2. The effects of different doses of Ni on the chlorophyll content, dry weight, GSH and Ni concentrations of Xanthium strumarium $L .(n=3)$

\begin{tabular}{|c|c|c|c|c|c|c|}
\hline & \multirow{2}{*}{$\begin{array}{c}\mathbf{N i} \\
\left(\mathrm{mg} \mathrm{kg}^{-1}\right)\end{array}$} & \multicolumn{2}{|c|}{$\begin{array}{l}\text { Chlorophyll } \\
\text { (SPAD Unit) }\end{array}$} & \multirow{2}{*}{$\begin{array}{l}\text { Dry weight } \\
\left.\text { (g plant }^{-1}\right)\end{array}$} & \multirow{2}{*}{$\underset{\left(\mu \mathrm{g} \mathrm{mL} \mathbf{~ m}^{-1}\right)}{\mathbf{G S H}}$} & \multirow{2}{*}{$\begin{array}{l}\text { Ni concentration } \\
\left(\mathrm{mg} \mathrm{kg}^{-1}\right)\end{array}$} \\
\hline & & Old leaf & Young leaf & & & \\
\hline \multirow{5}{*}{$\begin{array}{c}\text { Xanthium } \\
\text { strumarium L. }\end{array}$} & 0 & $30.7 \mathrm{a}$ & $32.5 \mathrm{a}$ & $6.61 \mathrm{a}$ & $266 \mathrm{~b}$ & $5.03 \mathrm{e}$ \\
\hline & 50 & $28.6 \mathrm{~b}$ & $31.6 \mathrm{ab}$ & $6.50 \mathrm{a}$ & $281 \mathrm{ab}$ & $10.7 \mathrm{~d}$ \\
\hline & 100 & $28.5 \mathrm{~b}$ & $30.3 \mathrm{~b}$ & $5.88 \mathrm{~b}$ & $269 \mathrm{~b}$ & $21.7 \mathrm{c}$ \\
\hline & 200 & $28.4 \mathrm{~b}$ & $31.4 \mathrm{ab}$ & $5.61 \mathrm{bc}$ & 336 a & $49.5 \mathrm{~b}$ \\
\hline & 400 & $22.4 \mathrm{c}$ & $32.4 \mathrm{a}$ & $5.25 \mathrm{c}$ & $225 \mathrm{~b}$ & $101 \mathrm{a}$ \\
\hline Dose & $\mathrm{F}$ & $53.2 * *$ & $5.92 * *$ & $21.0 * *$ & $4.82 *$ & $3411 * *$ \\
\hline
\end{tabular}

$* * \mathrm{p} \leq 0.01$ statistically significant within error bounds

$* \mathrm{p} \leq 0.05$ statistically significant within error bounds

The chlorophyll content showed a decrease in the old and young leaves of Xanthium strumarium L. plant. The lowest chlorophyll contents were measured at $400 \mathrm{mg} \mathrm{kg}^{-1} \mathrm{Ni}$ application dose of old and young leaves (respectively 22.4 and 32.4 SPAD unit). On the contrary, a decrease was observed with increasing $\mathrm{Ni}$ doses according to control groups. The dry weights of the plant were varied between 6.61-5.25 $\mathrm{g} \mathrm{plant}^{-1}$. Nickel applications were decreased plant dry weights compared to the control plant $(\mathrm{p} \leq 0.01)$. Similar results were reported by Parlak (2016). The researcher has investigated the effect of Ni treatment $(0,25$ and $50 \mu \mathrm{M})$ on the growth and biochemical properties of wheat (Triticum aestivum L.). He found that the chlorophyll content of plants decreased with Ni applications. Rahman et al. (2005) were investigated the effect of increased doses of $\mathrm{Ni}(0,1.0,10$ and $100 \mu \mathrm{M})$ on the growth and composition of barley plants. They reported that the barley plant was generally adversely affected $\mathrm{Ni}$ application and the lowest chlorophyll content was measured at $100 \mu \mathrm{M}$ Ni treatment.

The increased application doses of $\mathrm{Ni}$ on the plant resulted with the lowest GSH concentration in the control group as $266 \mu \mathrm{g} \mathrm{mL}-1$ and the highest as $336 \mu \mathrm{g} \mathrm{mL}^{-1}$ at $200 \mathrm{mg} \mathrm{Ni} \mathrm{kg}^{-1}$ dose in the plant (Table 2). The GSH concentrations were decreased with $\mathrm{Ni}$ applications (Table 2). The lowest GSH concentration $\left(266 \mu \mathrm{g} \mathrm{mL}^{-1}\right)$ was obtained at the control group while the highest GSH concentration $\left(336 \mu \mathrm{g} \mathrm{mL}^{-1}\right)$ was obtained at $200 \mathrm{mg} \mathrm{Ni} \mathrm{kg}^{-1}$ application. Daghan et al. (2012) reported an enhancement of glutathione concentrations in transgenic and non-transgenic tobacco plants, which different $\mathrm{Ni}$ doses were applied to the soil.

The Ni concentration of the Xanthium strumarium L. plant increased (5.03-101 mg $\mathrm{kg}^{-1}$ ) with increasing $\mathrm{Ni}$ doses (Table 2). According to Alloway (1995), the critical concentration of $\mathrm{Ni}$ was obtained in tissues of the plant in the range of $10-100 \mathrm{mg} \mathrm{kg}^{-1}$. As Kaviani (2017) stated in a previous research by using Salicornia iranica plant, augmented $\mathrm{Ni}\left(0,50,250\right.$, and $\left.500 \mathrm{mg} \mathrm{Ni} \mathrm{kg}^{-1}\right)$ doses in the soil resulted in increased $\mathrm{Ni}$ concentration in the plants.

The Ni contents were increased with $\mathrm{Ni}$ application $(\mathrm{p} \leq 0.01)$ and the highest $\mathrm{Ni}$ content (530 $\mu \mathrm{g} \mathrm{plant}^{-1}$ ) was obtained at $400 \mathrm{mg} \mathrm{Ni} \mathrm{kg}^{-1}$ application (Fig. 1). Khan and Khan (2010) studying the effects of increased Ni application $(0,10,50,100,200$ and $400 \mathrm{mg} \mathrm{kg}^{-1}$ ) on growth and yield of chickpea plant. They found that the Ni content of the root, stem, and leaf of plants was increased with Ni applications. 


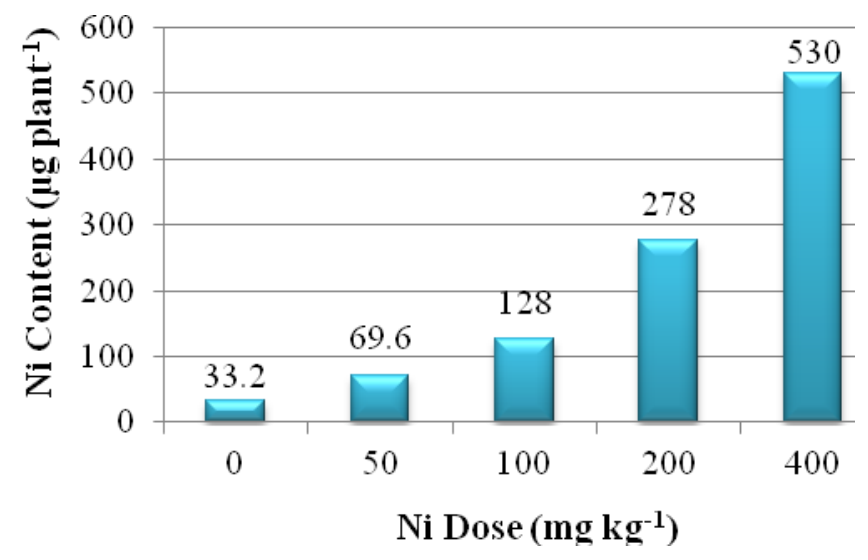

Figure 1. The effect of increasing Ni application on plant Ni content $(n=3)$

The effects of increasing doses of $\mathrm{Ni}$ on $\mathrm{N}, \mathrm{K}, \mathrm{Ca}$ and $\mathrm{Mg}$ concentrations of the plant were found statistically significant $(\mathrm{p} \leq 0.01)$. Compared to the control application the macro $(\mathrm{N}, \mathrm{P}, \mathrm{K}, \mathrm{Ca}$ and $\mathrm{Mg}$ ) element concentrations of plants were reduced with $\mathrm{Ni}$ applications (Table 3).

Table 3. The effect of different doses of $\mathrm{Ni}$ on $\mathrm{N}, \mathrm{P}, \mathrm{K}, \mathrm{Ca}$ and $\mathrm{Mg}$ concentration of Xanthium strumarium $L .(n=3)$

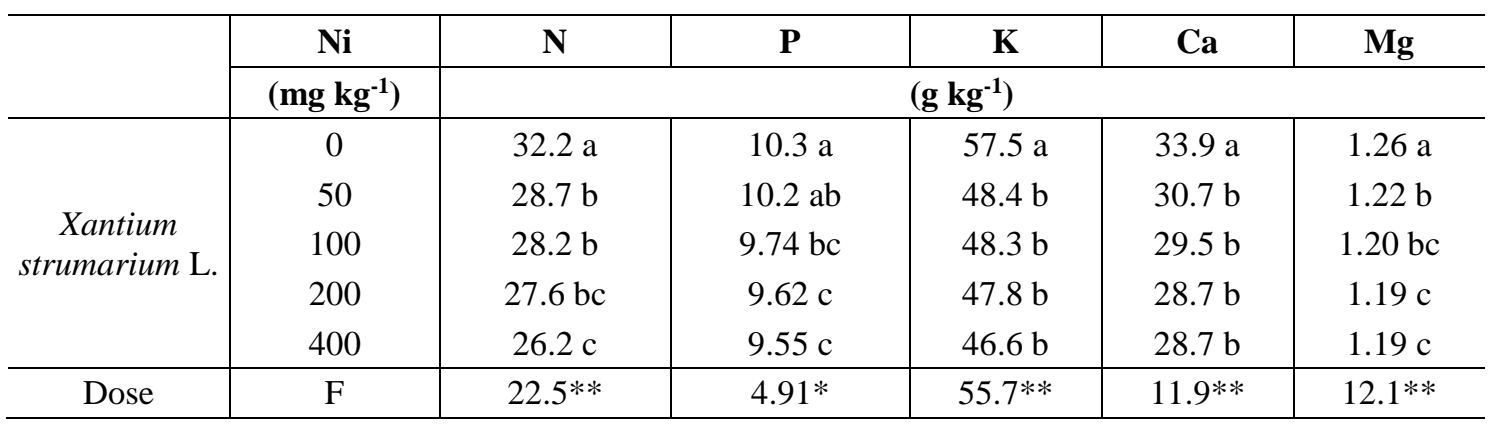

$* * \mathrm{p} \leq 0.01$ statistically significant within error bounds

$* \mathrm{p} \leq 0.05$ statistically significant within error bounds

Ahmad et al. (2011), investigated the phytotoxic effect of macro and micronutrients on the yield and macro and microelement concentration of Helianthus annuus L. plants with $\mathrm{Ni}$ applications $\left(0,10,20,30\right.$ and $\left.40 \mathrm{mg} \mathrm{L}^{-1}\right)$. They observed a decrease in concentrations of $\mathrm{N}, \mathrm{P}, \mathrm{K}, \mathrm{Ca}, \mathrm{Fe}, \mathrm{Zn}, \mathrm{Cu}$ and $\mathrm{Mn}$ elements by the increase of $\mathrm{Ni}$ doses, on the other hand Ahmad et al. (2009), reported that increased Ni (10, 20, 30, 40, 50 and $60 \mathrm{mg} \mathrm{L}^{-1}$ ) applications have been associated with the effect of 5 different sunflowers (Helianthus annuus L.) seeds, indicating a decrease in $\mathrm{Mg}$ and $\mathrm{K}$ contents due to increased Ni dose.

It was observed that the effects of $\mathrm{Ni}$ applications on microelement concentrations of Xanthium strumarium L. plant were statistically significant $(\mathrm{p} \leq 0.01)($ Table 4$)$.

When the rise in $\mathrm{Ni}$ doses was compared with the control group on the microelements $(\mathrm{Fe}, \mathrm{Zn}$, and $\mathrm{Mn}$ ) of the plants, it was found that the concentration of these elements was decreased, while the $\mathrm{Cu}$ element concentration was increased (Table 4). Previous studies have shown that high amount of $\mathrm{Ni}$ applications can reduce the 
amount of Fe (Chen et al., 2009; Pandey and Sharme, 2002). Rahman et al. (2005) reported that microelements $(\mathrm{Fe}, \mathrm{Zn}$ and $\mathrm{Mn})$ reduced in other applications except for $1.0 \mu \mathrm{M} \mathrm{Ni}$, whilst investigating the effect of $\mathrm{Ni}$ doses $(0,1.0,10$ and $100 \mu \mathrm{M})$ on the growth and composition of barley plants.

Table 4. The effect of different doses of $\mathrm{Ni}$ on $\mathrm{Fe}, \mathrm{Zn}, \mathrm{Cu}$, and $\mathrm{Mn}$ concentrations in Xanthium strumarium $L .(n=3)$

\begin{tabular}{c|c|c|c|c|c}
\hline & $\mathbf{N i}$ & $\mathbf{F e}$ & $\mathbf{Z n}$ & $\mathbf{C u}$ & $\mathbf{M n}$ \\
\cline { 2 - 6 } & $\left(\mathbf{m g ~ k g}^{-\mathbf{1}}\right)$ & \multicolumn{4}{|c}{$\left(\mathbf{m g ~ k g}^{-\mathbf{1}}\right)$} \\
\hline \multirow{3}{*}{ Xantium } & 0 & $49.0 \mathrm{a}$ & $15.7 \mathrm{a}$ & $43.0 \mathrm{c}$ & $116 \mathrm{a}$ \\
strumarium L. & 50 & $48.3 \mathrm{a}$ & $15.3 \mathrm{ab}$ & $45.3 \mathrm{c}$ & $111 \mathrm{ab}$ \\
& 100 & $45.7 \mathrm{a}$ & $13.7 \mathrm{bc}$ & $45.7 \mathrm{c}$ & $107 \mathrm{~b}$ \\
& 200 & $45.0 \mathrm{a}$ & $12.9 \mathrm{c}$ & $54.3 \mathrm{~b}$ & $107 \mathrm{~b}$ \\
\hline Dose & 400 & $35.0 \mathrm{~b}$ & $10.9 \mathrm{~d}$ & $63.3 \mathrm{a}$ & $106 \mathrm{~b}$ \\
\hline
\end{tabular}

$* * \mathrm{p} \leq 0.01$ statistically significant within error bounds

\section{Conclusion}

Increasing doses of $\mathrm{Ni}$ used in this study induced a decrease in chlorophyll content and dry weight of plants. The main causes of this decrease are thought to be the accumulation of the Ni element in plant tissues at toxic levels and the negative effects of metabolisms that allow the plant to grow and develop.

The effect of $\mathrm{Ni}$ applications on GSH concentration according to the control group was varied between $225-336 \mu \mathrm{g} \mathrm{mL}^{-1}$, which was exhibited the highest at $200 \mathrm{mg} \mathrm{Ni} \mathrm{kg}{ }^{-}$ ${ }^{1}$ application, while the lowest Ni content was at $33.2 \mu \mathrm{g}$ plant $^{-1}$ and the highest $530 \mu \mathrm{g}$ plant $^{-1}$ with $400 \mathrm{mg} \mathrm{Ni} \mathrm{kg}^{-1}$.

The content of Ni has increased with varying dose applications, and no chlorosis or necrosis has been observed in the plant. Xanthium strumarium L. plant is found to be an important step for investigating the biochemical and physiological responses of plants against Ni toxicity and suitable for increasing the phytoremediation efficiency.

In addition, Xanthium strumarium is a native and aggressive weed in many countries. Although the species can be used in phytoremediation, it absolutely should be grown on controlled conditions.

\section{REFERENCES}

[1] Ahmad, M. S. A., Hussain, M., Ashraf, M., Ahmad, R., Ashraf, M. Y. (2009): Effect of nickel on seed germinability of some elite sunflower (Helianthus annuus L.) cultivars. Pakistan Journal of Botany 41: 1871-1882.

[2] Ahmad, M. S. A., Ashraf, M., Hussain, M. (2011): Phytotoxic effects of nickel on yield and concentration of macro-and micro-nutrients in sunflower (Helianthus annuus L.) achenes. - Journal of Hazardous Materials 185(2-3): 1295-1303.

[3] Alloway, B. J. (1995): Blackie Academic and Professional. Heavy Metals in Soils, $2^{\text {nd }}$ ed. - Chapman and Hall Press, London, UK.

[4] Alpaslan, M., Gunes, A., Inal, A. (1998): Test Technique. - Ankara University Faculty of Agriculture, Publication No: 1502. 
[5] Bek, Y. (1986): Research and Trial Methods. - Lecture notes. Publication No: 92. Cukurova University, Faculty of Agriculture, Adana.

[6] Bouyoucos, G. J. (1951): A recalibration of hydrometer for making mechanical analysis of soils. - Agronomy Journal 43: 434-438.

[7] Bremner, J. M., Mulvaney, C. S. (1982): Nitrogen-Total. - In: Page, A. L, Miller, R. H., Keeney, D. R. (eds.) Methods of Soil Analysis. Part 2. Chemical and Microbiological Properties, $2^{\text {nd }}$ ed. American Society of Agronomy, Madison, WI, pp. 595-624.

[8] Cakmak, I., Marschner, H. (1992): Magnesium deficiency and high light intensity enhance activities of superoxide dismutase, ascorbate peroxidase and glutathione reductase in bean leaves. - Plant Physiology 98: 1222-1227.

[9] Cesur, C., Senkal, B. C. (2016): The Investigation of the potential into culture of cocklebur (Xanthium strumarium L.). - KSU Journal of Agriculture and Nature 19(1): 72-75.

[10] Chen, C., Huang, D., Liu, J. (2009): Functions and toxicity of nickel in plants: recent advances and future prospects. - Clean-Soil, Air, Water 37(4-5): 304-313.

[11] Chaney, R. L. (1988): Metal Speciation and Interactions among Elements Affect Trace Element Transfer in Agricultural and Environmental Food-Chains. - In: Kramer, J. R., Allen, H. E. (eds.) Metal Speciation: Theory, Analysis and Applications. Lewis Publishers, Chelsea, MI, pp. 218-260.

[12] Daghan, H. (2007): Phytoremediation: cleaning of contaminated areas using plant GAP. V. Agriculture Congress, Proceedings Book, October 17-19, Sanliurfa, Turkey, pp.362367.

[13] Daghan, H., Ozturk, M. (2015): Soil Pollution in Turkey and Remediation Methods. - In: Hakeem, K. R., Sabir, M., Ozturk, M., Mermut, A. (eds.) Soil Remediation and Plants: Prospects and Challenges. Academic Press, Elsevier, New York, pp. 287-312.

[14] Daghan, H., Koleli, N., Uygur, V., Arslan, M., Onder, D., Goksun, V., Agca. N. (2012): Investigation of the use of transgenic tobacco plant in the treatment of Cd-contaminated soils by phytoextraction. - Soil and Water Journal 1(1): 1-6.

[15] Dos Reis, A. R., Barcelos, J. P. Q., Osório, C. R. W. S., Santos, E. F., Lisboa, L. A. M., Santini, J. M. K., Santos, M. J. D., Junior, E. F., Campos, M., Figueiredo, P. A. M., Lavres, J., Gratão, P. L. (2017): A glimpse into the physiological, biochemical and nutritional status of soybean plants under Ni-stress conditions. - Environmental and Experimental Botany 144: 76-87.

[16] Ebbs, S. D., Lasat, M. M., Brady, D. J., Cornish, J., Gordon, R., Kochain, L. V. (1997): Phytoextraction of cadmium and zinc from a contaminated soil. - Journal of Environmental Quality 26: 1424-1430

[17] Gerendás, J., Polacco, J. C., Freyermuth, S. K. Sattelmacher, B. (1999): Significance of nickel for plant growth and metabolism. - Journal of Plant Nutrition and Soil Science 162(3): 241-256.

[18] Gupta, C., Gupta, S. (1998): Trace element toxicity relationships to crop production and livestock and human health: implications for management. - Communications in Soil Science and Plant Analysis 29: 1491-1522.

[19] Gheibi, M. N., Malakouti, M. J., Kholdebarin, B., Ghanati, F., Teimouri, S., Sayadi, R. (2009): Significance of nickel supply for growth and chlorophyll content of wheat supplied with urea or ammonium nitrate. - Journal of Plant Nutrition 32(9): 1440-1450.

[20] Hamutoglu, R., Dincsoy, A. B., Cansaran-Duman, D., Aras, S. (2012): Biosorption, adsorption, phytoremediation methods and applications. - Turkish Bulletin of Hygiene and Experimental Biology 69(4): 235-253.

[21] Jaffré, T., Pillon, Y., Thomine, S., Merlot, S. (2013): The metal hyperaccumulators from New Caledonia can broaden our understanding of nickel accumulation in plants. Frontiers in Plant Science 4: 279. 
[22] Kacar, B. (1995): Chemical Analysis of Plant and Soil, III. Soil Analysis. - Ankara University, Faculty of Agriculture, Education, Research and Development Foundation, Publications No: 3, Ankara.

[23] Karaca, A., Turgay, O. C. (2012): Soil pollution. - Journal of Soil Science and Plant Nutrition 1: 13-19.

[24] Karenlampi, S., Schat, H., Vangronsveld, J., Verkleij, J. A. C., Lelie, D., Mergeay, M., Tervahauta, A. I. (2000): Genetic engineering in the improvement of plants for phytoremediation of metal polluted soils. - Environmental Pollution 107(2): 225-231.

[25] Kaviani, E., Niazi, A., Moghadam, A., Taherishirazi, M., Heydarian, Z. (2017): Phytoremediation of Ni-contaminated soil by Salicornia iranica. - Environmental Technology 16: 1-12.

[26] Khan, M. R., Khan, M. M. (2010): Effect of varying concentration of nickel and cobalt on the plant growth and yield of chickpea. - Australian Journal of Basic and Applied Sciences 4: 1036-1046.

[27] K1lıc, S., Agca, N., Karanlik, S., Senol, S., Aydin, M., Yalcin, M., Celik, I., Evrendilek, F., Uygur, V., Dogan, K., Aslan, S., Cullu, M. A. (2008): Detailed environmental studies of the Amik Plain. - State Planning Organization (SPO) Project. Project No: SPO2002K120480, Hatay (in Turkish).

[28] Kocaer, F. O., Baskaya, H. S. (2003): Remediation technologies for metal-contaminated soils. - Uludag University Journal of the Faculty of Engineering and Architecture 8(1): 121-131.

[29] Lindsay, W. L., Norvell, W. A. (1978): Development of a DTPA soil test for zinc, iron, manganese, and copper. - Soil Science Society of America Journal 42: 421-428.

[30] Loeppert, R. H., Suarez, D. L. (1996): Carbonate and Gypsum. - In: Spark, D. L. (ed.) Methods of Soil Analysis. Part 3. Chemical Methods. Soil Science Society of America, Madison, Wisconsin, USA, pp. 437-474.

[31] Lombi, E., Zhao, F. J., Dunham, S. J., McGrath, S. P. (2001): Phytoremediation of heavy metal contami-nated soils: natural hyper-accumulation versus chemically enhanced phytoextraction. - Journal of Environmental Quality 30: 1919-1926.

[32] Marschner, H. (1995): Mineral Nutrition of Higher Plants. - Academic Press, New York.

[33] Murakami, M., Ae, N. (2009): Potential for phytoextraction of copper, lead, and zinc by rice (Oryza sativa L.), soybean (Glycine max [L.] Merr.), and maize (Zea mays L.). Journal of Hazardous Materials 162: 1185-1192.

[34] Olsen, S. R., Cole, C. V., Watanabe, F. S., Dean, L. A. (1954): Estimation of available phosphorus in soils by extraction with sodium bicarbonate. - USDA Circular No. 939, U. S. Department of Agriculture, Washington DC.

[35] Pandey, N., Sharma, C. P. (2002): Effect of heavy metals $\mathrm{Co}^{2+}, \mathrm{Ni}^{2+}$ and $\mathrm{Cd}^{2+}$ on growth and metabolism of cabbage. - Plant Science 163(4): 753-758.

[36] Parlak, K. U. (2016): Effect of nickel on growth and biochemical characteristics of wheat (Triticum aestivum L.) seedlings. - NJAS-Wageningen Journal of Life Sciences 76: 1-5.

[37] Prasad, M. N. V., Freitas, H. M. (2003): Metal hyperaccumulation in plants - biodiversity prospecting for phytoremediation technology. - Electronic Journal of Biotechnology 6(3): 285-321.

[38] Rahman, H., Sabreen, S., Alam, S., Kawai, S. (2005): Effects of nickel on growth and composition of metal micronutrients in barley plants grown in nutrient solution. - Journal of Plant Nutrition 28(3): 393-404.

[39] Rehman, K., Fatima, F., Waheed, I., Akash, M. S. H. (2018): Prevalence of exposure of heavy metals and their impact on health consequences. - Journal of Cellular Biochemistry 119(1): 157-184.

[40] Richards, L. A. (1954): Diagnosis and Improvement of Saline and Alkali Soils. Handbook 60 94. United States Department of Agriculture, Washington, DC.

[41] Soil Survey Staff (1951): Soil Survey Manual. -U.S. Department of Agriculture, Handbook No, 18. U.S Government Print Office, Washington, DC. 
[42] Syam, N., Wardiyati, T., Maghfoer, M. D., Handayanto, E., Ibrahim, B., Muchdar, A. (2016): Effect of accumulator plants on growth and nickel accumulation of soybean on metal-contaminated soil. - Agriculture and Agricultural Science Procedia 9: 13-19.

[43] Yang, X., Baligar, V. C., Martens, D. C., Clark, R. B. (1996): Plant tolerance to nickel toxicity: II nickel effects on influx and transport of mineral nutrients in four plant species. - Journal of Plant Nutrition 19(2): 265-279.

[44] Yankov, B., Delibaltova, V., Bojinov, M. (2000): Content of Cu, Zn, Cd and Pb in the vegetative organs of cotton cultivars grown in industrially polluted regions. Rasteniev'dni Nauki 37(7): 525-531. 